\title{
Effect of microwave-assisted system on transesterification of castor oil with ethanol
}

\author{
Gina M. Hincapié1, Sabine Valange ${ }^{2}$, Joël Barrault ${ }^{2}$, Jorge A. Moreno ${ }^{1}$, Diana P. López ${ }^{1 凶}$
}

\begin{abstract}
A systematic study of microwave-assisted transesterification of castor oil was conducted in the presence of ethanol and of potassium hydroxide as catalyst. Effects of various reaction parameters such as reaction time, catalyst concentration, reaction temperature and ethanol-oil molar ratio were analyzed. Ethyl esters were successfully produced by microwave-assisted transesterification. The maximum yield was $80.1 \%$ at $60^{\circ} \mathrm{C}, 10: 1$ alcohol: oil molar ratio, 1.5\% potassium hydroxide and $10 \mathrm{~min}$. The results show that there was a reduction in reaction time for microwave-assisted transesterification as compared to conventional heating, yields were slightly affected by temperature from $40-70^{\circ} \mathrm{C}$; this indicates a significant effect of microwaves even at low temperatures.
\end{abstract}

Keywords: Microwave radiation; castor oil; biodiesel; transesterification.

Edited by Alberto Acosta四

1 Institute of Chemistry, Universidad de Antioquia, Medellín, Colombia.

2 Institut de Chimie des Milieux et Matériaux de Poitiers, ENSIP-Université de Poitiers, Poitiers, France.

Received: 22-02-2014 Accepted: 20-03-2014

Published on line: 27-05-2014

Citation: Hincapié GM, Valange S, Barrault J, Moreno JA, López DP (2014) Effect of microwave-assisted system on transesterification of castor oil with ethanol. Universitas Scientiarum 19(3): 193-200 doi: 10.11144/Javeriana.SC19-3.emas

Funding: Universidad de Antioquia; Colciencias; University of Poitiers.

Electronic supplementary material: N/A

\section{Introduction}

Due to the increasing energy demand and the environmental problems related with the use of fossil fuels, it has become necessary to develop alternative fuels. Among these, biodiesel is an interesting option because it is biodegradable, non-toxic and it is produced from renewable sources (Ma \& Hanna 1999, Karmakar et al. 2010). Biodiesel is mainly produced by transesterification of vegetable oils or animal fats with short chain alcohols such as methanol or ethanol (Figure 1), with glycerol as a co-product (Fukuda et al. 2001, Pinto et al. 2005). The use of methanol is more common than ethanol because of its low cost and high reactivity but there is an increasing interest in the use of ethanol because it is renewable, non-toxic and it is safer to handle (Pisarello et al. 2010, Brunschwig et al. 2012). 


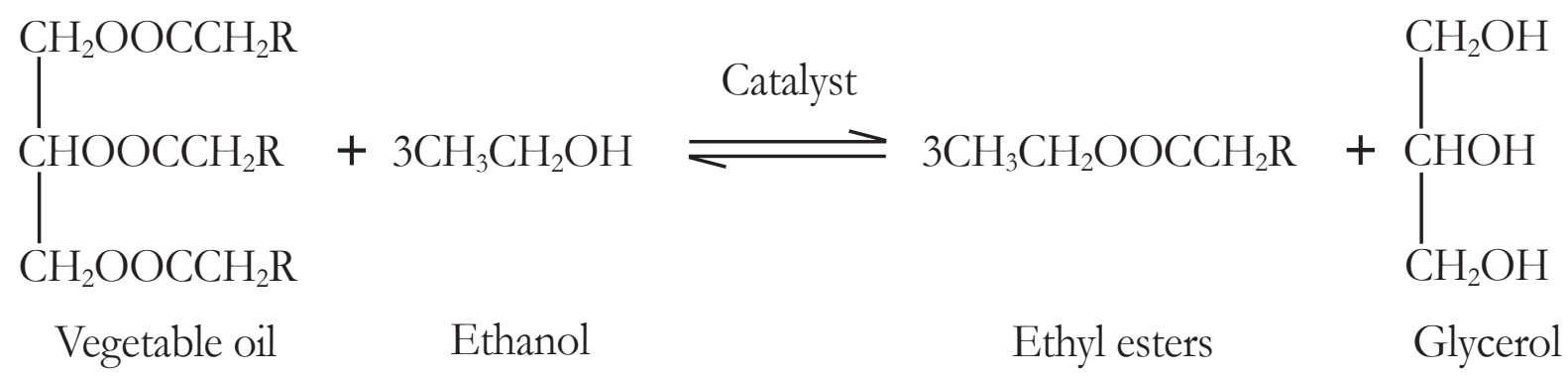

Fig. 1. Scheme of transesterification reaction

Edible oils like soybean, sunflower and palm oil have been used for biodiesel production. However, aiming to reduce biodiesel production costs, the use of less expensive feedstock such as non-edible oils, animal fats and waste cooking oils has gained interest (Berchmans \& Hirata 2008). Among these feedstocks, castor oil, obtained from Ricinus communis $L$. seeds has been identified as an important nonedible raw material (Meneghetti et al. 2006, Lavanya et al. 2012, Madankar et al. 2013). Opposed to other vegetable oils, it is characterized by its indigestibility, solubility in alcohols, high hygroscopicity and high viscosity (Scholz \& Nogueira da Silva 2008). It is mainly constituted of triglycerides of ricinoleic acid (12-hydroxy-cis-octadec-9-enoic acid) in which the presence of a hydroxyl group at C-12 imparts several unique chemical and physical properties that are exploited in the pharmaceutical and chemical industry (Meneghetti et al. 2006).

Generally, transesterification reaction is performed under conventional heating, nevertheless, over the past few years, microwave irradiation has gained interest as an alternative heating system for this type of reactions (Hernando et al. 2007, Azcan \& Yilmaz 2013, Yadav \& Kadam 2013, Yuan \& Shu 2013). The changing electrical field component of microwave radiation interacts with the dipoles of the molecules increasing their rotation and as a consequence heat is generated due to molecular friction. Hence, microwave irradiation increases the reaction rate and higher yields are generally obtained in short times, as compared to conventional heating (Azcan \& Danisman 2007, Manco et al. 2012).
Some recent studies on the transesterification of castor oil have been carried out under microwave irradiation. Koberg and Gendanken (2012) reported the transesterification of castor oil with methanol and $\mathrm{SrO}$ as a catalyst under a two-stage (extraction and transesterification) and a one-stage method (in situ transesterification) using three techniques: conventional heating, sonochemistry and microwave irradiation. For the two-stage method, the authors found the highest yield of FAMEs as $52.7 \%$ and a conversion of $99.5 \%$ using microwave irradiation as a heating source. On the other hand, $57.2 \%$ yield of FAMEs and a conversion of $99.9 \%$ were achieved in a one-stage method lasting 5 min using microwave irradiation. Yuan et al. (2011) used acid catalysts $\left(\mathrm{NaHSO}_{4} \cdot \mathrm{H}_{2} \mathrm{O}\right.$ and $\left.\mathrm{AlCl}_{3}\right)$ and a base catalyst $\left(\mathrm{Na}_{2} \mathrm{CO}_{3}\right)$ to evaluate transesterification of castor oil under microwaves. Best results were obtained at $65^{\circ} \mathrm{C}, 18: 1$ molar ratio of methanol to castor oil, $7.5 \mathrm{wt} \%$ of catalyst with respect to castor oil, $200 \mathrm{~W}$ microwave radiation power and $120 \mathrm{~min}$ of reaction time, at these reaction conditions, they obtained yields of $74,73,90 \%$ using $\mathrm{NaHSO}_{4} \cdot \mathrm{H}_{2} \mathrm{O}, \mathrm{AlCl}_{3}$ and $\mathrm{Na}_{2} \mathrm{CO}_{3}$ respectively. They also found that microwave heating consumes less energy than conventional heating to achieve the same amount of FAME.

There is a diversity of scientific literature on transesterification of castor oil with ethanol (de Oliveira et al. 2005, Meneghetti et al. 2006, Plentz Meneghetti et al. 2006, Varma \& Madras 2007, Albuquerque et al. 2009; de Lima da Silva et al. 2009, Cavalcante et al. 2010, Efeovbokhan et al. 2012, Martínez Arias et al. 2012, Thomas et al. 2013). In a study developed by our group (Hincapié et al. 2011), conventional biodiesel 
production from crude castor oil using ethanol was conducted. The content of ethyl esters was determined by ${ }^{1} \mathrm{H}$ NMR. The higher conversions (around 95\%) were found after esterification (reaction time $1 \mathrm{~h}$ ) and transesterification (reaction time $1 \mathrm{~h}$ ) using an alcoholoil molar ratio of 60 and a temperature of $60^{\circ} \mathrm{C}$.

However, little information is available on transesterification of castor oil with ethanol assisted by microwaves (Perin et al. 2008) and, as far as the authors are aware, no systematic studies have been carried out modifying reaction parameters to optimize this transesterification with homogeneous catalysts. Thus, we have conducted a study analyzing the effect of microwave irradiation on biodiesel production from castor oil using ethanol. Variables such as reaction time, catalyst concentration, reaction temperature and ethanol-oil molar ratio were considered.

\section{Methodology}

Materials: Analytical grade isopropanol (>99.5\%), potassium hydroxide (85\%), sulfuric acid (96\%), anhydrous sodium sulfate $(99 \%)$ and tetradecane $(99.5 \%)$, were used as purchased without any further purification. Absolute ethanol (99.7\%) was used for transesterification reactions. Ethyl ricinoleate $(87 \%)$ was purchased from TCI Europe. Refined castor oil (CODEX) and ethyl esters mixture for gas chromatography $(\mathrm{GC})$ quantifications, were provided by VALAGRO Carbone Renouvelable Poitou-Charentes.

\section{Procedures:}

\section{Microwave assisted transesterification: A} MicroSYNTH (Microwave synthesis labstation, Milestone Inc.) microwave unit with a power output range from 0 to $1000 \mathrm{~W}$ was used to perform transesterification reactions. The system was equipped with a reflux condenser, a magnetic stirrer bar and a fiber optic temperature sensor placed in a thermowell (PTFE).

First, the effect of reaction time and catalyst concentration was analyzed by placing a castor oil sample (10 g) into a three-neck round-bottom reaction flask. Initially, the catalyst $(\mathrm{KOH})$ was dissolved in the desired amount of ethanol and the resulting solution was then added to the oil. The catalyst was used at three different concentrations $0.5 \%, 1.0 \%$ and $1.5 \%$ and we evaluated four different reaction times $(3,5,7$ or $10 \mathrm{~min}$ ); temperature was maintained at $60^{\circ} \mathrm{C}$ and the ethanol:oil molar ratio was 10:1. The mixture was irradiated at a maximum of $250 \mathrm{~W}$. At the end of the reaction, the mixture was cooled at room temperature and $\mathrm{H}_{2} \mathrm{SO}_{4}$ was added to neutralize the $\mathrm{KOH}$ catalyst. Centrifugation was used to separate the glycerol phase while ethanol was removed from biodiesel phase by vacuum distillation and further purified with hot water washes and dried over anhydrous $\mathrm{Na}_{2} \mathrm{SO}_{4}$. The effect of temperature $\left(40,50,60,70^{\circ} \mathrm{C}\right)$ and the effect of ethanol:oil $(4: 1,6: 1$ or 10:1) molar ratio were evaluated, with a reaction time of $10 \mathrm{~min}$ and a catalyst concentration of $1.5 \%$. Each experiment was performed in duplicate.

Analysis: The acid value of the oil was determined by an acid-base tritration technique (modificed ASTM D974, 2006) using a standard solution of $\mathrm{KOH} 0.5 \mathrm{~N}$. Saponification and hydroxyl indexes were determined under the NF ISO 3657 and NF T60-213 regulations respectively.

A GC Varian CP-3380 instrument equipped with a FID detector and a capillary column BPX-70 (25 m x $0.32 \mathrm{~mm}$ ID $\times 0.25 \mu \mathrm{m}$ ) was used to analyze the products using tetradecane as internal standard.

\section{Results and discussion}

The acid value of the oil was $2.05 \mathrm{mg} \mathrm{KOH} / \mathrm{g}$ sample. Saponification and hydroxyl values were $180.2 \mathrm{mg}$ $\mathrm{KOH} / \mathrm{g}$ sample and $179.8 \mathrm{mg} \mathrm{KOH} / \mathrm{g}$ sample, respectively; these results are in agreement with previous reports (Benavides et al. 2007). Fatty acid composition for castor oil CODEX is reported in Table 1 (data provided by supplier). Molecular weight of the oil was estimated at $926 \mathrm{~g} / \mathrm{mol}$ using this composition.

Table 1. Fatty acid composition of castor oil CODEX (provided by supplier)

\begin{tabular}{ll}
\hline \multicolumn{1}{c}{ Fatty acid } & Composition / \%wt. \\
\hline Ricinoleic acid & $85-92$ \\
Linoleic acid & $2.5-7.0$ \\
Oleic acid & $2.5-6.0$ \\
Palmitic acid & $\leq 2.0$ \\
Estearic acid & $\leq 2.5$ \\
Linolenic acid & $\leq 1.0$ \\
\hline
\end{tabular}


Results of transesterification for different reaction times and catalyst concentrations (Table 2) indicated that for a blank reaction performed under the same experimental conditions (molar ratio ethanol:oil 10:1, $\mathrm{T}=60^{\circ} \mathrm{C}, 2 \mathrm{~h}$ ) a yield of $0.74 \%$ was obtained. Also, biodiesel yield increases with catalyst concentration, obtaining the highest yield with $1.5 \%$ of $\mathrm{KOH}$. Table 2 also shows that, for the same catalyst concentration, biodiesel yield does not change significantly with reaction time, except for $10 \mathrm{~min}$, where the yields increased. Taking into account that the yields are not significantly increased for transesterification at $30 \mathrm{~min}$, we decided to continue the work with $10 \mathrm{~min}$ as reaction time; therefore, further experiments were performed using $1.5 \% \mathrm{KOH}$ and $10 \mathrm{~min}$. To compare, a $79 \%$ yield was obtained using a conventional heating system for $1 \mathrm{~h}$, which shows that microwave heating strongly increases transesterification rate.
In accordance with the Arrhenius equation Eq(1), the rate of a chemical reaction depends on the preexponential factor $(A)$ and the activation energy $\left(E_{a}\right)$ (Lidström et al. 2001). From experiments involving microwaves, some authors have found evidence of the modification of the pre-exponential factor A (Binner et al. 1995, Polshettiwar \& Varma 2010). This factor describes the molecular mobility and depends on the frequency of collisions at the reaction interface(Lidström et al. 2001).

$$
k=A e^{-\mathrm{Ea} / \mathrm{RT}}
$$

It is also necessary to consider that polar solvents are required for microwave heating, and the ability of a solvent to absorb microwave energy and to convert this energy into heat is related with the loss angle, $\delta$, which is usually expressed in the form of a tangent (Lidström et al. 2001) Eq. (2):

Table 2. Effect of reaction time and catalyst concentration on biodiesel yield. Molar ratio ethanol-oil $10: 1, \mathrm{~T}=60^{\circ} \mathrm{C}$

\begin{tabular}{ccc}
\hline Reaction time / min & $\begin{array}{c}\text { Catalyst } \\
\text { concentration / \% / w }\end{array}$ & Biodiesel yield / \% \\
\hline 3 & 0.5 & 26.5 \\
& 1.0 & 57.2 \\
5 & 1.5 & 64.6 \\
& 0.5 & 29.5 \\
& 1.0 & 56.0 \\
7 & 1.5 & 61.6 \\
& 0.5 & 29.0 \\
& 1.0 & 54.2 \\
10 & 1.5 & 66.3 \\
& 0.5 & 34.3 \\
& 1.0 & 70.3 \\
& 1.5 & 80.1 \\
(Blank under microwaves) & 0.5 & 13.9
\end{tabular}




$$
\tan \delta=\frac{\epsilon^{\prime \prime}}{\epsilon^{\prime}}
$$

Where $E^{\prime}$ is the dielectric constant and represents the ability of a dielectric material to store electrical potential energy under the influence of an electric field. The loss factor, $E$ ", quantifies the efficiency with which the absorbed energy is converted into heat (Lidström et al. 2001).

Ethanol has a higher loss tangent (0.941) compared with other solvents as methanol (0.659) (Dressen 2009). Due to its loss tangent, ethanol couples better than methanol with microwave irradiation which induces dipolar polarization as a consequence of dipole-dipole interactions of polar molecules with the electromagnetic field (Perreuz \& Loupy 2006). This phenomenon results in a rapid heating leading to an efficient intermolecular mixing and agitation (i.e increase in effective collisions), therefore, increasing the reaction rate compared to conventional heating. Nevertheless, non-thermal effects related with the change on pre-exponential factor $A$ should not be discarded (Polshettiwar \& Varma 2010) and could be the subject of further investigations.

The effects of temperature and ethanol:oil molar ratio were also evaluated and the results are shown in Figure 2a and $2 b$.
As seen in Figure 2a, there are two temperature ranges in which there is not a marked increase on biodiesel yield as temperature increases. In the first one $\left(40-50^{\circ} \mathrm{C}\right)$, biodiesel yield is around $72 \%$, which is an encouraging result considering that transesterification is generally conducted nearly to the boiling point of the solvent $\left(78^{\circ} \mathrm{C}\right.$ for ethanol). In the second temperature range $\left(60-70^{\circ} \mathrm{C}\right)$, biodiesel yield is around $80 \%$. These results suggest that the phenomenon of dipolar polarization generated by microwave irradiation is effective even at very lower temperatures compared to the boiling point of the solvent, condition that is strictly necessary in conventional heating.

When the ethanol:oil molar ratio is reduced from 10 to 4 (Figure 2b), biodiesel yield decreases from 80.1 to $48.3 \%$. This observation is in agreement with the above-mentioned positive effect of microwave irradiation, the higher the amount of ethanol, which is the polar reagent sensitive to microwaves, the higher the number of dipole-dipole interactions.

\section{Conclusions}

Microwave heating was a useful technique to obtain high biodiesel yields from castor oil in short reaction times, achieving better performances at lower times
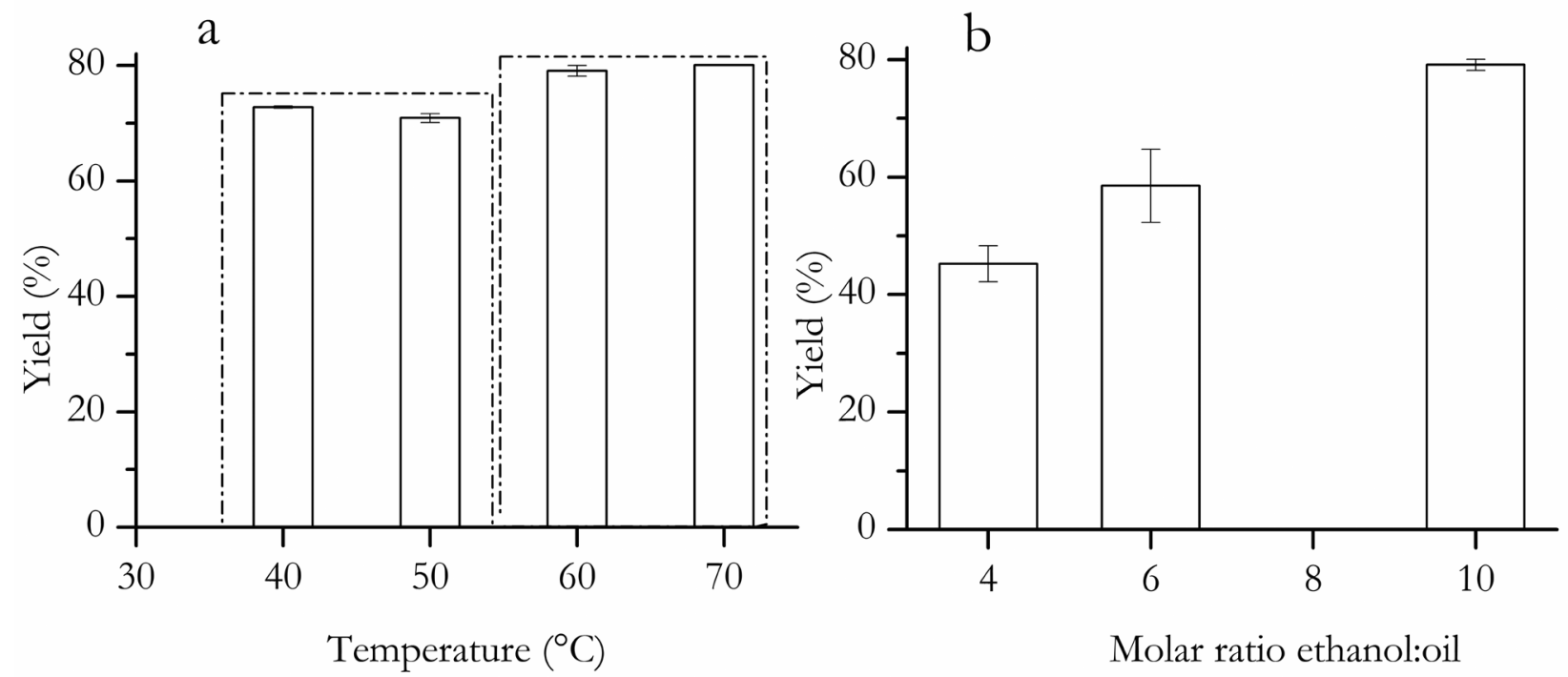

Fig. 2. a. Effect of temperature on biodiesel yield (KOH 1.5\%, 10 min, molar ratio ethanol-oil 10:1). b. Effect of molar ratio ethanol-oil on biodiesel yield $\left(\mathrm{KOH} 1.5 \%, 10 \mathrm{~min}, 60^{\circ} \mathrm{C}\right)$ 
compared with conventional heating. Moreover, temperature has low effect on yield, which confirms that the influence of microwaves is effective even at low temperatures, contrary to that observed with conventional method. These results are encouraging for the future analysis of transesterification assisted by microwaves using ethanol derived from biomass or using low-quality oils.

\section{Acknowledgements}

The authors acknowledge (i) CODI - University of Antioquia for financing the project 01540 "Evaluación de la producción de biodiesel a partir de las especies Ricinus communis L. y Jatropha curcas L." and also for the financial support through Programa Sostenibilidad 2013-2014, (ii) The University of Poitiers for the PhD student internship and (iii), VALAGRO Carbone Renouvelable Poitou-Charentes for samples, analysis and fruitful discussions. G.H. acknowledges Colciencias and the University of Antioquia for her Ph.D. scholarship.

\section{Conflict of interest}

There are no conflicts of interest with funding sources or institutions.

\section{References}

Albuquerque MCG, Cavalcante Jr. CL, Torres AE, Azevedo D, Parente Jr. E (2009) Transesterification of Castor Oil Using Ethanol: Effect of Water Removal by Adsorption onto Zeolite 3A. Energy \& Fuels 23:11361138 doi:10.1021/ef8009684

Azcan N, Danisman A (2007) Alkali catalyzed transesterification of cottonseed oil by microwave irradiation. Fuel 86(17-18):2639-2644 doi:10.1016/j. fuel.2007.05.021

Azcan N, Yilmaz O (2013) Microwave assisted transesterification of waste frying oil and concentrate methyl ester content of biodiesel by molecular distillation. Fuel 104:614-619 doi:10.016/j. fuel.2012.06.084

Benavides A, Benjumea P, Pashova V (2007) Castor oil biodiesel as an alternative fuel for diesel engines. Dyna 74(153):141-150

Berchmans HJ, Hirata S (2008) Biodiesel production from crude Jatropha curcas L. seed oil with a high content of free fatty acids. Bioresource Technology 99(6):17161721 doi:10.1016/j.biortech.2007.03.051
Binner JGP, Hassine NA, Cross TE (1995) The possible role of the pre-exponential factor in explaining the increased reaction rates observed during the microwave synthesis of titanium carbide. Journal of Materials Science 30(21):5389-5393 doi:10.1007/BF00351548

Brunschwig C, Moussavou W, Blin J (2012) Use of bioethanol for biodiesel production. Progress in Energy and Combustion Science 38(2):283-301 doi:10.1016/j. pecs.2011.11.001

Cavalcante KSB, Penha MNC, Mendonça KKM, Louzeiro HC, Vasconcelos ACS, et al.(2010) Optimization of transesterification of castor oil with ethanol using a central composite rotatable design (CCRD). Fuel 89(5):1172-1176 doi:10.1016/j.fuel.2009.10.029

De Lima da Silva N, Benedito Batistella C, Maciel Filho R, Maciel MRW (2009) Biodiesel Production from Castor Oil: Optimization of Alkaline Ethanolysis. Energy \& Fuels 23(11):5636-5642 doi:10.1021/ef900403j

De Oliveira D, Di Luccio M, Faccio C, Dalla Rosa C, Bender JP, et al.(2005) Optimization of Alkaline Transesterification of Soybean Oil and Castor Oil for Biodiesel Production. Applied Biochemistry and Biotechnology 121-124:553-560 doi:0273-2289

Dressen M (2009) Microwave heating in fine chemical applications: role of heterogeneity. Doctorate thesis. Technische Universiteit Eindhoven, Eindhoven, Holanda

Efeovbokhan VE, Ayoola A, Anawe PAL, Oteri O (2012) The Effects of Trans-Esterification of Castor Seed Oil Using Ethanol, Methanol and their Blends on the Properties and Yields of Biodiesel. International Journal of Engineering and Technology 2(10):1734-1742

Fukuda H, Kondo A, Noda H (2001) Biodiesel fuel production by transesterification of oils. Journal of Bioscience and Bioengineering 92(5):405-416

Hernando J, Leton P, Matia MP, Novella JL, AlvarezBuilla J (2007) Biodiesel and FAME synthesis assisted by microwaves: Homogeneous batch and flow processes. Fuel 86(10-11):1641-1644 doi:10.1016/j. fuel.2006.11.003

Hincapié G. Mondragón F, López D (2011) Conventional and in situ transesterification of castor seed oil for biodiesel production. Fuel 90:1618-1623 doi:10.1016/j. fuel.2011.01.027

Karmakar A, Karmakar S, Mukherjee S (2010) Properties of various plants and animals feedstocks for biodiesel production. Bioresource Technology 101(19):72017210 doi:10.1016/j.biortech.2010.04.079

Koberg M, Gedanken A (2012) Direct Transesterification of Castor and Jatropha Seeds for FAME Production by Microwave and Ultrasound Radiation Using a SrO Catalyst. BioEnergy Research 5(4):958-968 doi:10.1007/s12155-012-9210-6 
Lavanya C, Murthy IYLN, Nagaraj G, Mukta N (2012) Prospects of castor (Ricinus communis L.) genotypes for biodiesel production in India. Biomass and Bioenergy 39:204-209. doi:10.1016/j.biombioe.2012.01.008

Lidström P, Tierney J, Wathey B, Westman J (2001) Microwave assisted organic synthesis - a review. Tetrahedron 57(589):9225-9283

Ma F, Hanna MA (1999) Biodiesel production: a review. Bioresource Technology 70:1-15.

Madankar CS, Pradhan S, Naik SN (2013) Parametric study of reactive extraction of castor seed (Ricinus communis L.) for methyl ester production and its potential use as bio lubricant. Industrial Crops and Products 43:283290 doi:10.1016/j.indcrop.2012.07.010

Manco I, Giordani L, Vaccari V, Oddone M (2012) Microwave technology for the biodiesel production: Analytical assessments. Fuel 95:108-112 doi:10.1016/j. fuel.2011.09.047

Martínez Arias EL, Fazzio Martins P, Jardini Munhoz AL, Gutierrez-Rivera L, Maciel Filho R (2012) Continuous Synthesis and in Situ Monitoring of Biodiesel Production in Different Microfluidic Devices. Industrial \& Engineering Chemistry Research 51:10755-10767 doi:10.1021/ie300486v

Meneghetti SMP, Meneghetti MR, Wolf CR, Silva EC, Lima GES, et al.(2006) Ethanolysis of castor and cottonseed oil: A systematic study using classical catalysts. Journal of the American Oil Chemists' Society 83(9):819-822 doi:10.1007/s11746-006-5020-3

Perin G, Álvaro G, Westphal E, Viana LH, Jacob RG, et al.(2008) Transesterification of castor oil assisted by microwave irradiation. Fuel 87(12):2838-2841 doi:10.1016/j.fuel.2008.01.018

Perreuz L, Loupy A (2006) Nonthermal effects of microwaves in organic synthesis. In A. Loupy (ed.) Microwaves in organic synthesis. Second Edi. WileyVCH Verlag GmbH \& Co, Darmstadt, Germany, pp 134-218

Pinto AC, Guarieiro LLN, Rezende MJC, Ribeiro NM, Torres EA, et al.(2005) Biodiesel: an overview. Journal of the Brazilian Chemical Society 16(6b):1313-1330 doi:10.1590/S0103-50532005000800003

Pisarello ML, Dalla Costa B, Mendow G, Querini CA (2010) Esterification with ethanol to produce biodiesel from high acidity raw materials. Fuel Processing Technology 91(9):1005-1014 doi:10.1016/j. fuproc.2010.03.001

Plentz Meneghetti SM, Meneghetti MR, Wolf CR, Silva EC, Lima GES (2006) Biodiesel from Castor Oil: A Comparison of Ethanolysis versus Methanolysis. Energy \& Fuels 20(5):2262-2265 doi:10.1021/ ef060118m
Polshettiwar V, Varma R (2010) Fundamentals of Aqueous Microwave Chemistry. In Polshettiwar V \& Varma R (eds.) Aqueous Microwave Assisted Chemistry Royal Society of Chemistry RSC Cambridge, UK. pp 1-9

Scholz V, Nogueira da Silva J (2008) Prospects and risks of the use of castor oil as a fuel. Biomass and Bioenergy 32(2):95-100 doi:10.1016/j.biombioe.2007.08.004

Thomas TP, Birney DM, Auld DL (2013) Optimizing esterification of safflower, cottonseed, castor and used cottonseed oils. Industrial Crops and Products 41:102-106 doi:http://dx.doi.org/10.1016/j. indcrop.2012.03.023

Varma M N, Madras G (2007) Synthesis of Biodiesel from Castor Oil and Linseed Oil in Supercritical Fluids. Industrial \& Engineering Chemistry Research 46(1):1-6 doi:10.1021/ie0607043

Yadav GD, Kadam AA (2013) Selective engineering using $\mathrm{Mg}-\mathrm{Al}$ calcined hydrotalcite and microwave irradiation in mono-transesterification of diethyl malonate with cyclohexanol. Chemical Engineering Journal 230:547557 doi:10.1016/j.cej.2013.06.075

Yuan H, Shu Q (2013) Synthesis of Biodiesel from Castor Oil Catalyzed by Cesium Phosphotungstate with the Assistance of Microwave. Applied Mechanics and Materials 291-294:300-306 doi:10.4028/www.scientific. net/AMM.291-294.300

Yuan H, Yang B, Zhang H, Zhou X (2011) Synthesis of Biodiesel Using Castor Oil under Microwave Radiation. International Journal of Chemical Reactor Engineering, 9(A71):1-11 doi:10.1515/1542-6580.2562 
Efecto de microondas en la transesterificación de aceite de higuerilla

Resumen. Se realizó un estudio sistemático del efecto de la radiación microondas en la transesterificación de aceite de higuerilla con etanol en presencia de hidróxido de potasio como catalizador. Diversos parámetros fueron analizados, entre ellos el tiempo de reacción, concentración de catalizador, temperatura y relación molar etanol-aceite. De acuerdo con los resultados, la transesterificación asistida por microondas resultó útil para la producción de etilésteres obteniéndose un rendimiento máximo de $80.1 \%$ a $60^{\circ} \mathrm{C}$, una relación molar alcohol: aceite de 10:1, 1.5\% de hidróxido de potasio y 10 min de reacción. Se observó una reducción en el tiempo de reacción para la transesterificación asistida por microondas comparada con el calentamiento convencional. Los resultados muestran que los rendimientos son ligeramente afectados por la temperatura en el rango $40-70^{\circ} \mathrm{C}$ lo que indica un efecto importante de las microondas incluso a bajas temperaturas.

Palabras clave: Radiación microondas; aceite de higuerilla; biodiesel; transesterificación.
Efeito microondas em transesterificaçáo do óleo de rícino

Resumo. O presente artigo, foi realizado um estudo sistemático da transesterificação assistida por irradiação de microondas com óleo de rícino na presença de etanol e de hidróxido de potássio como catalizador. Analisou-se os efeitos da variação alguns parâmetros da reação, tais como, tempo de reação, concentração de catalisador, temperatura de reação e proporção molar de óleo de etanol. De acordo com os resultados, os ésteres etílicos foram produzidos com êxito por transesterificação assistida por microondas, obtendo um rendimento máximo de $80.1 \%$ a $60{ }^{\circ} \mathrm{C}$, razão molar de 10:1 álcool: óleo, $1.5 \%$ de hidróxido de potássio em $10 \mathrm{~min}$. Houve uma redução no tempo de reação de transesterificação assistida por microondas, em relação ao aquecimento convencional. Os resultados mostram que os rendimentos são ligeiramente afetados pela temperatura, no intervalo de $40-70{ }^{\circ} \mathrm{C}$, indicando um efeito significativo de microondas mesmo a baixas temperaturas.

Palavras-chave: Radiação de microondas; óleo de rícino; biodiesel; transesterificação. 